\title{
My Country, Right or Wrong: If the Cause Is Just, Is Anything Allowed?
}

David Whetham

Follow this and additional works at: https://scholarlycommons.law.case.edu/ijel

Part of the Applied Ethics Commons, Business Law, Public Responsibility, and Ethics Commons, Leadership Studies Commons, and the Legal Ethics and Professional Responsibility Commons

\section{Recommended Citation}

Whetham, David (2017) "My Country, Right or Wrong: If the Cause Is Just, Is Anything Allowed?," The International Journal of Ethical Leadership: Vol. 4 , Article 5.

Available at: https://scholarlycommons.law.case.edu/ijel/vol4/iss1/5

This Article is brought to you for free and open access by the Cross Disciplinary Publications at Case Western Reserve University School of Law Scholarly Commons. It has been accepted for inclusion in The International Journal of Ethical Leadership by an authorized administrator of Case Western Reserve University School of Law Scholarly Commons. 


\title{
My Country, Right or Wrong
}

If the Cause is Just, is Anything Allowed?

\author{
David Whetham \\ Director of the King's Centre for Military Ethics, and Reader \\ in Military Ethics in the Defense Studies Department, King's \\ College London
}

\begin{abstract}
If one's cause is just, why should the righteous be treated the same as the unjust? If one side is clearly right and the other side is clearly wrong, shouldn't the side that is in the right be permitted to do whatever is required to win? Why should the "good" side be forced to fight with "one hand tied behind its back" when the "bad" side doesn't care about the rules and refuses to adhere to them? This article addresses these questions, arguing that it is often difficult to know with absolute certainty that one is on the "right" side, and there are good reasons for adhering to limits in one's conduct even when convinced that one's country does indeed have justice on its side.
\end{abstract}

\section{How Do You Know You Are on the Right Side and Does it Matter?}

Traditionally, within the just war canon of thought, there exists a distinction between the jus ad bellum (what is required to justify going to war) and the jus in bello levels of war (what can legitimately be done within that conflict). This distinction between the two levels of conflict, in theory, allows us to draw a line of moral responsibility between the decision to go to war and the actual conduct of that war. Soldiers are not necessarily responsible for the decision to send them to war (except as far as they participate as members of a democratic state). However, they are responsible for the actual conduct of the war-fighting it in a legitimate way. While determining exactly where this line is drawn is not always straightforward, Michael Walzer $(1992,39)$ suggests that we know that the most senior of military officers straddle this line between the two levels, and in doing so, this usefully gives us a pretty good idea of where that moral division should be made. 
While distinct, the two levels of war are still clearly related in a number of ways. For example, while one cannot make an unjust cause better by fighting for it "well," one can certainly undermine an otherwise just cause by fighting it in way that outrages the "common decency of mankind" (Whetham 2010b, 17). However, if one is to accept this separation as a dividing line of moral responsibility as well, it seems to answer the first of our questions immediately- "how do you know if you are on the right side and does it matter?" The division of moral responsibility appears to allow soldiers to participate in wars even when they are not entirely convinced that it is the right thing to do precisely because they are not responsible for the decision to go to war. Therefore it does not matter if they are "on the right side," for that is simply not their concern. Nor should they be held accountable for being "on the wrong side" if they lose. As Imiola (2014, 21) points out: "Wehrmacht soldiers after the Second World War and Iraqi soldiers after the Gulf War were not viewed as guilty for the crime of war nor punished for fighting for an unjust cause." Shakespeare captures the same reasoning in his play Henry $V$ (Act 4, Scene 1), where there is an exchange between soldiers on the eve of the Battle of Agincourt:

BATES:... we know enough, if we know we are the king's subjects: if his cause be wrong, our obedience to the king wipes the crime of it out of us.

WILLIAMS: But if the cause be not good, the king himself hath a heavy reckoning to make, when all those legs and arms and heads, chopped off in battle.

Writing at about the same time as Shakespeare, Francisco de Vitoria (quoted in Walzer 1992, 39) argued that embracing this distinction was important for the security of the state:

If subjects can not serve in war except they are first satisfied of its justice, the State would fall into grave peril and the door would be opened to wrongdoing...if subjects in a case of doubt do not follow their prince to the war, they expose themselves to the risk of betraying their state to the enemy, and this is a much more serious thing than fighting against the enemy despite a doubt.

Going back even further, in the fourth century Augustine argued that rulers had an obligation to maintain the peace for their realm (Fortin and Kries 
1994, 222). It was this very obligation to maintain peace that paradoxically gave those rulers the duty to wage war if that was what was required to uphold the peace on behalf of their people. Therefore, subjects were obliged to participate in a war declared by such a legitimate ruler for the common good (Bellamy 2006, 28). One can hardly be blamed for something over which one has no choice.

This traditional approach to the question has many contemporary supporters as well. For example, David Fisher (2014) argues that just as Augustine saw the legitimacy of rulers as coming from their role as protector of the common good, so too must the military today understand its role within a democracy: the military's role is to obey orders from the civil authority. The civil authority itself derives its legitimacy from the mandate provided by the society it represents along with the necessary checks and balances of due democratic process. When the state makes a decision to go to war, and that decision is in accord with due democratic principles, it is not up to the individual soldier to question this. Indeed, some argue that were they to do so en masse it would potentially lead to chaos (Wall 2010, 222). Therefore, the logic is clear: in the absence of clear evidence to the contrary, soldiers on both sides of a dispute are required to give their own leaders the benefit of the doubt.

However, the traditional argument was actually developed further by Vitoria with the addition of a very important qualification when he stated that there were limits as to how far soldiers could wash their hands of moral responsibility, even in war (Reichberg, Syse, and Begby 2006, 318-19). Specifically, he argued that it was possible that someone could be faced with "arguments and proofs of the injustice of war so powerful, that even citizens and subjects... may not use ignorance as an excuse for serving as soldiers... [I]f the war seems patently unjust to the subject, he must not fight, even if he is ordered to do so by the prince." If one was unsure or simply had some loosely formulated doubts, then one's duty is to put such doubts aside and obey the king/prince/president, for surely he is in the better position to judge. However, knowingly obeying a clearly unjust or illegal order crosses the moral boundary and makes the soldier just as culpable as the king. While Vitoria was writing nearly 500 years ago, this is a theme that still has clear contemporary relevance (Whetham 2010c, 74). Indeed, Vitoria's important qualification "represents a succinct account of the legal arguments regarding the limitations on obedience and the duty of dissent raised during the Nuremberg war crimes trials following World War II" 
(Lucas 2009). Just as there are some acts that are heinously wrong, surely there are some wars that appear so blatantly unjustifiable that one cannot claim the defense of simply following superior orders if one takes part. We do not expect our individual soldiers to be moral automata, but how far into the political realm do we rightly want their moral questioning to go?

Today, all professional militaries around the word acknowledge that there is a duty to disobey or disregard a blatantly illegal order. At the same time however, there is also a clear expectation that such duties are limited to tactical level considerations: it is not up to the soldier to question the policy of his or her government; so one can disagree at the ballot box but not in the barracks or in the context of combat. The assumption is that most soldiers are simply not in a position to know all the relevant facts about their government's decision to go to war and so are not able to reach a suitably informed judgment on the justice or injustice of the war. At this level they have what is referred to as "invincible ignorance" (see Sola 2009). If faced with an illegal order on a local, direct level where doing the right or wrong thing can be clearly determined, the individual involved has a clear requirement to "do the right thing," which may involve refusing to obey the instruction. So for example, Zupan argues, "if a lieutenant in a fit of rage orders a sergeant to bayonet a baby to 'inspire' villagers to provide information... [t] here is no ambiguity. The order is a clear assault against human decency, a clear violation of jus in bello proscriptions." However, if a soldier has doubts about the justice of the actual war itself, "the jus ad bellum assessments are far more complex and at a higher level of abstraction than the scenario about stabbing the baby" (Zupan 2014, 90). The traditional view is that the access to the knowledge that is required for a definitive answer at the ad bellum level is often simply beyond the scope of most people in the chain of command, apart from those at the very top. The common military institutional expectation is therefore that for the vast majority of people involved, "they should exercise humility and... defer to those who are in a better position to judge" (Ellner, Robinson, and Whetham 2014a, 8).

One of the practical implications of this graded moral responsibility is that soldiers on both sides of the battle-just and unjust - should be treated the same. This forms the basis of the moral equality of combatants that has underpinned our traditional understanding of responsibility regarding war. Even where giving the benefit of the doubt is not an issue, Vitoria and Aquinas accept that error may induce belligerents to believe that they are in the right, when in fact they might actually be squarely at fault. 
This can obviously lead to situations in which the "guilty party (sincerely) believes itself to be innocent" (Reichberg, Syse, and Begby 2006, 317). After all, very few people would deliberately fight for a cause they knew was wrong. Because of the lack of metaphysical certainty when it comes to this area, Vitoria demonstrates clearly why both sides are obliged to afford their opponents some respect and conduct their conflict within limits: it doesn't matter "who started it." This sense of moral equality (at least as far as the soldiers, if not their political masters, are concerned) is beautifully articulated on the Kemal Atatürk Memorial in Gallipoli: "There is no difference between the Johnnies and the Mehmets to us where they lie side by side now here in this country of ours."

\section{Contemporary Challenges}

This traditional "default" position at the heart of the just war tradition has come under increasing pressure in recent years from a number of different directions (e.g., McMahan 2009; Rodin 2011). Some argue that the context has fundamentally changed, that unlike in Vitoria's day, the average citizen in a Western liberal democracy with a healthy civic society and a free press holding the government to account has the potential to be far better informed about what is going on in the world. The assumption that "our political masters know best" has rather too frequently been shattered by "Dodgy Dossiers," fabricated intelligence reports, and political scandals. The degree of public outrage at the decision to go to war in Iraq in 2003 demonstrated that it appears that the princes in that case have turned out to be no better informed than anyone else. Perhaps in an age of wars of national survival, it was imperative to give the benefit of the doubt to the ruler, but having the same confidence when confronted with what has been called a "war of choice" in which vital national interests are not obviously at stake does not seem quite so straightforward. At the same time, modern soldiers are better educated and better informed than their predecessors. Everybody has access to the ubiquitous media, meaning that apart from certain types of very short notice deployment, only those who choose not to find out about the world (or are forced to rely on only biased media/ propaganda) remain in a true state of ignorance (Zupan 2014). Military institutions in all of the democratic states around the world spend time and effort in trying to ensure that they mold people capable of making appropriate ethical decisions in the complex security environment in which they are expected to work. Their moral reasoning is nurtured precisely because 
the environment does not always easily lend itself to easy answers. When such training is combined with unfettered access to pertinent information Ellner $(2014,347)$ suggests that "service members at all levels are epistemologically capable of exercising moral agency responsibly and sincerely." Unjust wars get fought at least in part because those fighting them fail to recognize this and do not challenge the orders they are given (Robinson 2009), choose not to look hard enough into the causes (McMahan 2009), or ignore their professional responsibilities to withhold their service (resign, seek reassignment, apply for conscientious objector status, etc.) if they judge it is being used for illegitimate purposes (Wolfendale 2009). ${ }^{1}$

If arguments such as these carry weight, it is difficult to see how military personnel who are engaged in fighting an unjust war can be totally excused from moral responsibility for fighting in such a war. "It cannot become permissible to do an otherwise impermissible act just because the responsibility for it would go to someone else" (McMahan 2014, xii). Brian Orend $(2006,109)$ suggests that we may consider such persons to be like minor accomplices to a major crime: perhaps they are not fully responsible for the jus ad bellum violations involved in engaging in the war in the first place. Nonetheless, by going along with it anyway, they are still not totally blameless. Such thinking gnaws away at the traditional separation of the levels of moral responsibility. While retaining the traditional moral dividing lines is a position robustly defended by many people (e.g., Bergeron, Fisher, and Skerker in Ellner, Robinson, and Whetham 2014b), "my country, right or wrong" no longer sounds quite as convincing to many people in the military in the context of contemporary decisions about resort to armed force.

\section{Where Does This Leave the 'Common" Soldier Trying to Serve in a Democratic State?}

While it can appear obvious which side has more relative merits than the other when one is observing a conflict from the outside, or with the comfortable distance of historical hindsight, making the same decision from within one of the parties to a conflict is rather harder. Being able to determine whose side of an argument is more just is obviously not an exact science. Even with the amazing range of sources and information available

1. Wolfendale (2009) has argued that if the military is to be considered a profession at all, then its members must have a professional obligation to withhold their services if the mission is not in the interests of the state as a whole. She argues that such a professional obligation falls on both the individual and the organization. 
in a networked, twenty-first century liberal democracy, it can be very hard to find a truly balanced assessment of contentious arguments.

There was much talk and discussion about "evidence" and "proof" of weapons of mass destruction (WMDs) in the run-up to the Iraq War in 2003. From many conversations that this author had with serving military personnel at the time, there was a feeling that either the other arguments put forward regarding the violations of ceasefire provisions, etc., were sufficient in themselves to justify military action, or that there was probably some further compelling evidence regarding WMDs that could not be put into the public domain for "security reasons." Effectively, many military personnel who took part in Iraqi Freedom later that year despite their doubts had consciously or subconsciously applied Vitoria's test and decided that they owed their Prince the benefit of the doubt (even if some were later to feel betrayed as events unfolded).

It might be useful to ask whom does one actually serve as a professional soldier. If the answer is "one's country," where does that leave the military when the political elite take the country to a war not supported by the people (or even in extreme cases, against the people)? This is, of course, even in democratic states not a purely hypothetical issue: Britain's Chief of the Defense Staff, General Sir Nicholas Houghton (2013), has recognized that the type of overseas expeditionary operations that are currently the norm can create a potential disconnect between public opinion and policy decisions regarding war and peace: "The UK's armed forces have never, in the 40 years I have known, been held in such popular high regard. But the purposes to which they have most recently been put has seldom been more deeply questioned."

It would be churlish not to recognize that at least some of this disconnect comes from the lingering controversy surrounding that decision to invade Iraq in 2003. The scale of the disagreement was unprecedented, dwarfing even the Vietnam protests from the previous century. On February 15, 2003, more than 600 cities worldwide were involved in what has been described as the "largest protest event in human history" (Walgrave and Rucht 2010, xiii). Official police figures put the attendance in London alone as well in excess of 750,000 people, and the BBC (2003) estimated that around a million attended, making it the largest march London had ever seen. In light of such divisions between government and a large percentage of the people, should the military try to serve the democratic will of the people rather than obey the directions of the governing authorities? Unfortunately, 
the matter is not as simple as looking at surveys to see what the majority of the population wishes. Williams $(2013,63)$ notes that depending on the way the question was framed, opinion polls in the period preceding the contentious war against Iraq in 2003 were contradictory at best.

Thankfully, professional soldiers in democratic states are not obliged to try to second-guess public opinion because the oath of allegiance they swear is to the constitution rather than to the ruler, the people, opinion polls, or even the government. On the face of it, this looks rather different in the UK, where those enlisted into the British Army or Royal Air Force actually swear to be faithful and bear true allegiance to the monarch. ${ }^{2}$ However, due to the UK being without a formal written constitution (at least one that can be found in a single document), the monarch effectively acts as the physical embodiment of the British constitution. This means that while the words may look rather difficult, the sentiment is effectively the same: it is a commitment to serve the state as a whole rather than simply the government or ruler of the day or the whims of raw public opinion. Coleman $(2012,38)$ notes that while the practical distinction as to the direction of the oath of obedience is in most situations entirely irrelevant, there can, on occasion, be profound implications. For example, the German military oath changed in 1934 from one swearing loyal service to the German people and country to an individual statement of unconditional obedience to Adolf Hitler, the Führer (this oath was obviously changed back at the end of World War II). The point is that this was problematic precisely because a professional military, at least in the modern era, is not supposed to serve an individual or even a class or a position. It is supposed to serve the whole state; it is there to provide the public good of security for the whole nation.

So does that mean that soldiers in democracies should just accept the orders from the people's representatives in the government? Granting the benefit of the doubt to the government and trusting in the judgment of those higher up in the chain of command might still be an important part of ingrained military thinking; however, reflecting the changing times, this is no longer the unqualified deference one might have expected from Henry V's army in 1415. Nor would such automatic deference even be necessarily expected today. For example, in the face of the vocal and widespread opposition in 2003, the British government took the unprecedented 
step of granting a parliamentary vote on military action even though the executive had the historical power vested in it to go to war without further discussion. This "constitutional novelty" looks likely to remain for future large-scale British military deployments (Williams 2013, 64) and, while it only went so far in meeting the "not in my name" objections from protesters, did allow all the people's representatives in Parliament to give a clear mandate to their military. Even in this case, though, the then Chief of the Defense Staff, Admiral Sir Michael Boyce, went further in a way that was again constitutionally unprecedented but also entirely in accordance with traditional thinking about gradated moral responsibility in such situations. He asked the UK Attorney General - the highest legal authority in the UK-for a clear ruling asking for a "yes or no answer" on the legality of the war (Torleton 2010). Only once satisfied with the ruling did Boyce commit British armed forces to the conflict. In this case, an objective judgment as to the war's justice was not what was being sought, but there was certainly much heated debate at the time as to whether the UK really should be going to war in Iraq with or without a specific UN Security Council Resolution. Anyone in the rest of the military who harbored any doubts about the war's legality were reassured in a very visible sense that the right questions had been asked by the right people and that the highest legal authority in the UK had been consulted on their behalf and given the legal "thumbs up" (even if this judgment has subsequently proved as controversial as the rest of the conflict).

This demonstration of the gradated moral responsibility assumes that those high enough in the military chain of command have access to all (or at least enough) of the information necessary to make an informed judgment. Vitoria made it clear that very senior military commanders have a specific professional responsibility to "speak truth to power" and examine the justice of a war, even if necessary, through their advice to the ruler, to try to avert a conflict they believe unjust. ${ }^{3}$ They are effectively charged with acting as the guardians of the military conscience. For this to work, there must be sufficient trust within the rest of the organization that those who do have access to the pertinent information at the political/strategic interface are actually asking the right questions on behalf of the rest of the organization, and indeed the country at large. General Sir Peter Wall $(2010,222)$ articulates for the case of the UK both this division of moral responsibility within the military and the 
duty that flows from it: "It is for the high command to ensure that intended operations satisfy jus ad bellum and to be prepared to reassure the members of the force that this is the case through the chain of command." As long as there is confidence that such questions have genuinely been asked, then those further down the chain of command-those who do not have access to the full information and comprehensive arguments-should be able to "park their doubts" and participate. ${ }^{4}$

Unless they are actually already convinced that the cause is blatantly or manifestly wrong, or their confidence in the veracity of the arguments for war is so small that all trust has been lost (perhaps due to a history of false assurances, forged evidence, or a decision-making system that is known to be false or corrupted), granting the benefit of the doubt to the state in such situations does not seem unjustified. It is also not clear to many that one should automatically choose not to fight even if one does decide that one's own side might have gotten it wrong. Isn't there a duty to defend one's state anyway? Admiral James B. Stockdale, distinguished veteran of the Vietnam War, long-term prisoner of war and subsequent founder of ethics education establishments at all levels of the U.S. Navy, provides an interesting case in point (see Stockdale 1995). He was present as an aviator during both of the Gulf of Tonkin incidents and knew for a fact that it was a U.S. ship that had fired first on August 2, 1964, and that no U.S. warship had been fired upon at all on August 4. The stated "just cause" was a lie. ${ }^{5}$ However, once Congress had passed its resolution, Admiral Stockdale accepted its decision and served his country. Was he really wrong to do so? Even if the reasons are not right, once your state has decided it is going to war, can you really turn your back on your fellow soldiers, your friends, and your country, just when it really does need you? Admiral Stockdale obviously thought not. Would refusing to serve in such circumstances even be compatible with the professional military ethic? Kasher $(2002,173)$ argues that in the Israeli context:

Comradeship is an essential value of military ethics...[A]cts of civil disobedience that take the form of refusal by reserve officers

4. What exactly those senior commanders are supposed to do if they are unable to amend an unjust policy is more difficult, highlighting debate even within traditional just war thinking. For example, while Vitoria would prioritize individual conscience in the face of such a clear moral challenge, advocating the resignation of one's commission for example, thinkers such as Suarez expect that once one has done one's duty to try and avert a morally wrong course of action and has proved unsuccessful, one is then expected to execute the Prince's orders. See Whetham (2010c: 74). See also Lucas (2009).

5. For the declassified official report into these events, see Hanyok (2000/1). 
and NCOs to serve within the framework of their combat units cause damage to the necessary sense of military comradeship. Thereby they inflict damage on the democratic regime, which owes its citizenry an effective military force of self-defense.

As a result, someone who refuses to participate on moral grounds in such circumstances, becoming a selective conscientious objector, "puts saving his own conscience above his responsibility to help his comrades. Many see this as incompatible not only with the necessary virtue of comradeship but also with the virtue of self-sacrifice" (Ellner, Robinson, and Whetham 2014b, 8). However, despite the complexities of the ad bellum considerations, it seems clear that obeying the rules in bello is much more straightforward. One is expected to uphold in bello considerations such as protecting civilians and causing no more harm to the enemy than military necessity demands regardless of the justification for the war, the authority on which it is waged, or the motivations one has for taking part in the fighting.

\section{Can the Rules Ever Be Set Aside?}

The War Convention is "a set of articulated norms, customs, professional codes, legal precepts, religious and philosophical principles, and reciprocal arrangements that shape our judgments of military conduct" (Walzer 1992, 44). It encompasses the commonly held idea that in war it is possible to use deadly force in a legitimate way. So, for example, in everyday life there is a general prohibition on murder, but that does not mean that all killing is considered murder. A police officer acting in self-defense against a deadly threat may be justified in killing an attacker. Such an act would not generally be regarded as murder. Similarly, when one uses lethal force on behalf of one's state or political community in a war, that too is generally not regarded as murder. It is accepted that it is not only excusable, but sometimes even worthy to kill in such situations (Whetham 2013, 116). Of course, that does not mean that all killing in war is justified, and it is still possible to commit murder even within a war (e.g., killing a surrendering combatant or deliberately targeting unarmed civilians). The War Convention, therefore, articulated through the laws of armed conflict, sets out what is acceptable and unacceptable practice in war. In one of his wartime speeches, Winston Churchill used the phrase "supreme emergency" to describe the existential peril that Britain found herself in when faced with imminent Nazi invasion. The idea was developed by Walzer (1992, 251-68) 
to explore whether it was permissible to break or set aside such rules in the face of "an imminent catastrophe" to a people. Using the example of the mission given to RAF's Bomber Command to target German cities, Walzer argued that extreme necessity may justify overriding the rights of innocent people on the ground, and therefore the shattering of the War Convention. Bomber Command was the only effective military instrument that Britain possessed at the time for taking the war to the Germans, and Britain's hard-pressed Russian allies desperately needed help in the face of Operation Barbarossa and reverses on every front. Given the minimal chance of getting through air defenses in daylight, it was necessary to fly at night, but the limitations of available military technology meant that only something the size of a city could actually be realistically targeted in such circumstances. To do so would obviously violate the absolute principle that one cannot deliberately target a civilian population, but given the terrible cost of defeat that would follow if the Nazi regime were to be successful, combined with the lack of viable military alternatives, violating such a principle could be argued to be justified in the circumstances. It should be noted here that despite a minority of dissent (Grayling 2007, 179-206), the British government, the people as a whole, and the airmen who carried out the attacks on the whole did not doubt the just cause of the war against Germany; so the primary issue here was whether otherwise wrongful conduct could justified by specific circumstances.

Is such an ethical position tenable? Walzer $(2004,46)$ recognizes just how hard it is to justify breaking the normal rules and also how limited any exception must be: as Britain's circumstance changed, new theaters of war opened up, new powerful allies joined the fight; long-range escorts were introduced, making daylight flying less deadly, while technology improved, making it possible to target more accurately, and most importantly, the threat of imminent invasion receded and the supreme emergency passed. As a result, the continued violation of the War Convention became less and less justifiable as the war continued (Walzer 1992, 261), and yet the bombing continued, actually increasing in intensity and destruction of civilian life. If the supreme emergency had ever truly existed, it had long since passed by the time 100,000 people were killed in Dresden in the spring of 1945. Whether or not the supreme emergency idea presents an ethically justifiable position at all is debated at some considerable length and divides ethicists (Cook 2007). Who is to judge the nature of such an existential threat? Wouldn't this be the thin end of the wedge when everything begins to 
look like a "supreme emergency" if you are the one under threat? "What lesser evils may a society commit when it believes it faces the greater evil of its own destruction?" (Ignatieff 2005, 1).

What is clearer in the present context is that while the rise of a genuinely existential threat cannot be ruled out in the future, political rhetoric aside, it is the challenge of discretionary wars that we are routinely faced with today, where it is political interests rather than national survival that are at stake. It does not matter which side one is on: in this type of conflict, there is no conceivable excuse today for abandoning the rules and violating the ethical norms of war (cf. Whetham 2010d, 254).

\section{Conclusion}

Modern soldiers are expected (and indeed trained) to ask questions, and it seems nonsensical to say that this questioning should cease at some imaginary line beyond which they are no longer capable of making decisions. At the same time, it is necessary to accept that to expect the perfect knowledge that may be presented in a philosophical thought experiment is not always realistic in the messy reality of everyday life, let alone the extraordinary circumstances surrounding a decision to go to war. It is not always possible to know whether one's own government has got it right, and to require the type of epistemic certainty before serving demanded by some of the just war tradition's contemporary challengers is surely asking too much. As long as there are sufficient checks, balances, and accountability in the political system and chain of command (and these are probably going to be more robust in a functioning democracy than in other forms of government), a soldier should be able to have confidence that he or she will not be sent to fight on the objectively unjust side of a conflict. While there are many good reasons to challenge the old, comfortable moral division of labor, perhaps the best we can do for now is continue to accept that certainty of an unjust cause is a reason not to participate, while also accepting that doubts are normal and even desirable in an effective fighting force if it is not to turn into some kind of all-annihilating horde.

At the same time, just as Vitoria and the Nuremberg principles attest in their own ways, there are limits on the service that any state can expect from its servants. Whatever the objective rights and wrongs of the conflict in which they are participating, and regardless of whether they believe their cause to be just, there are no special freedoms or permissions granted to one side over the other. It doesn't matter if you are on the "right" side, or 
whether the other side flouts or ignores every rule in the book, one is still bound to fight within the rules. So the ultimate issue is how one fights when ordered to fight by his or her country: here is where the matter of justice cuts most keenly for the serving soldier, and how one fights is at least as important as what one fights for.

\section{References}

Augustine, 1994. City of God. In: E.L., Fortin and D. Kries, eds. Augustine: political writings. Translated by M.W.Tkacz and D. Kries. Indianapolis: Hackett. Bk. XIV, chap. 13.

BBC News, 2003. Anti-war rally makes its mark, February 19. [online] Available at: http://news. bbc.co.uk/1/hi/uk/2767761.stm [Accessed January 20, 2014].

Bergeron, M., 2014. Selective conscientious objection: a violation of the social contract. In: A. Ellner, P. Robinson, and D. Whetham, eds. When soldiers say no: selective conscientious objection in the modern military. Farnham: Ashgate. pp.49-62.

Bellamy, A.J., 2006. Just wars: from Cicero to Iraq. Cambridge: Polity Press.

Coleman, S., 2012. Military ethics: an introduction with case studies. Oxford: Oxford University Press.

Cook, M.L., 2007. Michael Walzer's concept of "supreme emergency." Journal of Military Ethics, 6(2), pp.138-51.

Ellner,A., 2014. War resisters in the US and Britain: supporting the case for a right to selective conscientious objection? In:A. Ellner, P. Robinson, and D. Whetham, eds. When soldiers say no: selective conscientious objection in the modern military. Farnham: Ashgate. pp.213-37.

Ellner, A., Robinson, P., and Whetham, D., 2014a. Sometime they'll give a war and nobody will come. In: A. Ellner, P. Robinson, and D. Whetham, eds. When soldiers say no: selective conscientious objection in the modern military. Farnham:Ashgate. pp.1-15.

Ellner, A., Robinson, P., and Whetham, D., eds., 2014b. When soldiers say no: selective conscientious objection in the modern military. Farnham: Ashgate.

Fisher, D., 2014. Who guards the guards? the importance of civilian control of the military. In: A. Ellner, P. Robinson, and D. Whetham, eds. When soldiers say no: elective conscientious objection in the modern military. Farnham: Ashgate. pp.63-76.

Fortin, E.L. and Kries, D., eds., 1994. Augustine: political writings. Translated by M.W. Tkacz and D. Kries. Indianapolis: Hackett.

Grayling,A.C., 2007. Among the dead cities: is the targeting of civilians in war ever justified? London: Bloomsbury Publishing.

Hanyok, R.J., 2000/1. Skunks, bogies, silent hounds, and the flying fish: the Gulf of Tonkin mystery, 2-4 August 1964. Cryptologic Quarterly, 19(4)/20(1).

Houghton, N., 2013. Annual chief of the defence staff lecture 2013. [online] London: Royal United Services Institute. Available at: http://www.rusi.org/events/past /ref:E5284A3D06EFFD [Accessed January 20, 2014].

Ignatieff, M., 2005. The lesser evil: political ethics in an age of terror. Edinburgh: Edinburgh University Press. 
Whetham: My Country, Right or Wrong: If the Cause Is Just, Is Anything All

Whetham My Country, Right or Wrong

Imiola, B., 2014. The duty of diligence. In: A. Ellner, P. Robinson, and D. Whetham, eds. When soldiers say no: selective conscientious objection in the modern military. Farnham: Ashgate. pp.19-30.

Kasher, A., 2002. Refusals: neglected aspects. Israel Law Review, 36(3).

Lucas, G.R., 2009. Advice and dissent: the uniformed perspective. Journal of Military Ethics, 8(2), pp.141-61.

McMahan, J., 2009. Killing in war. Oxford: Oxford University Press.

McMahan, J., 2014. Foreword. In: A. Ellner, P. Robinson, and D. Whetham, eds. When soldiers say no: selective conscientious objection in the modern military. Farnham: Ashgate. pp.xi-xvi.

McMaster, H.R., 1998. Dereliction of duty: Johnson, McNamara, the joint chiefs of staff, and the lies that led to Vietnam. New York: Harper Perennial.

Orend, B. 2006. The morality of war. Toronto: Broadview.

Reichberg, G.M., Syse, H., and Begby, E., eds., 2006. The ethics of war: classic and contemporary readings. Oxford: Blackwell.

Robinson, P., 2009. Integrity and selective conscientious objection. Journal of Military Ethics, 8(1), pp. 34-47.

Rodin, D., 2011. Justifying harm. ethics, 122(1), pp.74-110. Skerker, M., 2014. An empirical defense of combatant moral equality. In: A. Ellner, P. Robinson, and D. Whetham, eds. When soldiers say no: selective conscientious objection in the modern military. Farnham: Ashgate. pp.77-88.

Sola,A., 2009. The enlightened grunt? invincible ignorance in the just war tradition. Journal of Military Ethics, 8(1), pp. 48-65.

Stockdale, J., 1995. Thoughts of a philosophical fighter pilot. Stanford: Hoover Institution Press.

Torleton,A., 2010. Goldsmith: why I changed Iraq war advice. Channel 4 News, January 27. [online] Available at: http://www.channel4.com/news/articles/uk/goldsmith +why+i+changed+iraq+war+advice/3518137.html [Accessed January 20, 2014].

United Nations High Commissioner for Human Rights, 2012. Syrian government forces and anti-government groups responsible for war crimes: UN Commission of Inquiry, August 15. [online] Available at: http://www.ohchr.org/Documents /HRBodies/HRCouncil/PRCoISyria15082012_en.pdf [Accessed January 20, 2014]

Vitoria, F. de, 1992. De indis et de jure belli, Part III.31. In: M. Walzer, Just and unjust wars, 3rd edition. New York: Basic Books. p.39.

Vitoria, F. de, 2006. On the law of war. In: G.M. Reichberg, H. Syse, and E. Begby, eds. The ethics of war: classic and contemporary readings. Oxford: Blackwell. pp. 308-32.

Walgrave, S., and Rucht, D., eds., 2010. The world says no to war: demonstrations against the War on Iraq. Minneapolis: University of Minnesota Press.

Wall, P., 2010. The ethical and legal challenges of operational command. In: D. Whetham, ed. Ethics, law and military operations. Basingstoke: Palgrave Macmillan. pp.221-9.

Walzer, M., 1992. Just and unjust wars: a moral argument with historical illustrations. 3rd edition. New York: Basic Books. 
Walzer, M., 2004. Arguing about war. New Haven and London:Yale University Press. Whetham, D., ed., 2010a. Ethics, law and military operations. Basingstoke: Palgrave Macmillan.

Whetham, D., 2010b. Ethics, law and conflict. In: D. Whetham, ed. Ethics, law and military operations. Basingstoke: Palgrave Macmillan. pp.10-28.

Whetham, D., 2010c. The just war tradition: a pragmatic compromise. In:D.Whetham, ed. Ethics, law and military operations. Basingstoke: Palgrave Macmillan. pp.65-89.

Whetham, D., 2010d. Ethics and the enduring relevance of just war theory in the 21st century. In: K. Buckley and G. Kassimeris, eds. The Ashgate research companion to modern warfare. Aldershot: Ashgate. pp.241-56.

Whetham, D., 2013. Drones and targeted killing: angels or assassins? In: B.J. Strawser, ed. Killing by remote control: the ethics of an unmanned military. Oxford: Oxford University Press. pp.69-83.

Williams, J., 2013. Not in my name? legitimate authority and liberal just war theory. In: A.F. Lang, C. O'Driscoll, and J. Williams, eds. Just war: authority, tradition, and practice. Washington, D.C.: Georgetown University Press. pp.63-80.

Wolfendale, J., 2009. Professional integrity and disobedience in the military. Journal of Military Ethics, 8(2), pp.127-40.

Zupan, D., 2014. Selective conscientious objection and the just society. In:A. Ellner, P. Robinson, and D. Whetham, eds. When soldiers say no: selective conscientious objection in the modern military. Farnham: Ashgate. pp.89-96.

(C) David Whetham (2015) From James Turner Johnson and Eric D. Patterson (eds), The Ashgate Research Companion to Military Ethics, published by Ashgate Publishing. See: http://www.ashgate.com/isbn/978147241628 